Int. J. Morphol.,

30(1):196-198, 2012.

\title{
Craniometrical Studies on the Skull of Tibetan Gazelle (Procapra Picticaudata)
}

\author{
Estudios Craneométricos en el Cráneo de la Gacela del Tibet (Procapra Picticaudata)
}

Lei Zhu

ZHU, L. Craniometrical studies on the skull of Tibetan Gazelle (Procapra Picticaudata). Int. J. Morphol., 30(1):196-198, 2012.

SUMMARY: A total of 10 skulls of Tibetan gazelle were utilized in this study. Craniometric measurements for 22 different parts of the skull were made. Skull indices and ratios were calculated. A skull index of $43.22 \pm 0.44$, a cranial index of $58.37 \pm 0.80$ and a facial index of $116.37 \pm 1.24$ were obtained.

KEY WORDS: Craniometry; Skull; Procapra Picticaudata.

\section{INTRODUCTION}

Procapra picticaudata Hodgson, 1846, a unique endangered wild animal, is considered endemic to the Tibetan Plateau and commonly called the Tibetan gazelle. It belongs to Order Artiodactyle, suborder Ruminantia, Family Bovidae, Subfamily Antilopinae. The poaching of this typical hoofed mammal is very serious and its number declines drastically, so it is listed as a threatened Class II species in China and considered "Near Threatened" by the International Union for Conservation of Nature and Natural Resources (Leslie, 2010).

The knowledge of the morphometric measurements of skull is of great importance for surgical interference of collection of pathological conditions. The morphometric study of the domestic animal skull has been documented (Sarma, 2006; Özcan et al., 2010), but the literature of craniometrical characteristics of Procapra Picticaudata is few. Groves (1967) had described the morphology of the genus Procapra Hodgson of different areas and measured a few skulls of the Procapra. The study was undertaken to establish a baseline data on the morphometric measurements of the skull of Tibetan gazelle.

\section{MATERIAL AND METHOD}

A total of 10 skulls of Tibetan Gazelle were utilized in this study. These heads were obtained from the poachers, so their ages were unknown. As female Tibetan gazelle bears no horns, the sex of the specimens is easy to distinguish to be male. The skulls were macerated in accordance with the method described by Simoens et al. (1994) and Onar (1999). 22 different craniometrical parameters were recorded with the help of measuring scale, thread and digital vernier calipers. These measurements were obtained by using the methods described by Onar and Onar et al. (2001). The cephalic indices and ratios were calculated as described by Brehm et al. (1985) and Onar. All investigated parameters are expressed as mean \pm SD.

Definitions of measuring points on the cranium (Figs. 1, 2 and 3): Akrokranion (A), Ectorbitale (Ect), Entorbitale (Ent), Euryon (Eu), Nasion (N), Nasointermaxillare (Ni), Rhinion (Rh), Supraorbitale (Sp), Basion (B), Premolare $(\mathrm{Pm})$, Palatinoorale $(\mathrm{Po})$, Prosthion $(\mathrm{P})$, Opisthion $(\mathrm{O})$.

Measurement of the cranium (Figs. 1, 2 and 3): Skull length (akrokranion-prosthion), Upper neurocranium length (akrokranion-frontal midpoint), Facial length (frontal midpoint-prosthion), Short upper cranium length (akrokranion-rhinion), Cranial length (akrokranion-nasion), Viscerocranial length (nasion-prosthion), Nasal suture length (nasion-rhinion), least distance between the horn core tips, Maximum width of the neurocranium (euryon-euryon), least diameter of the horn core base, Maximum zygomatic width (zygion-zygion), Basal length (basion-prosthion), Premolareprosthion, short skull length (premolare-basion), Oral palatal 


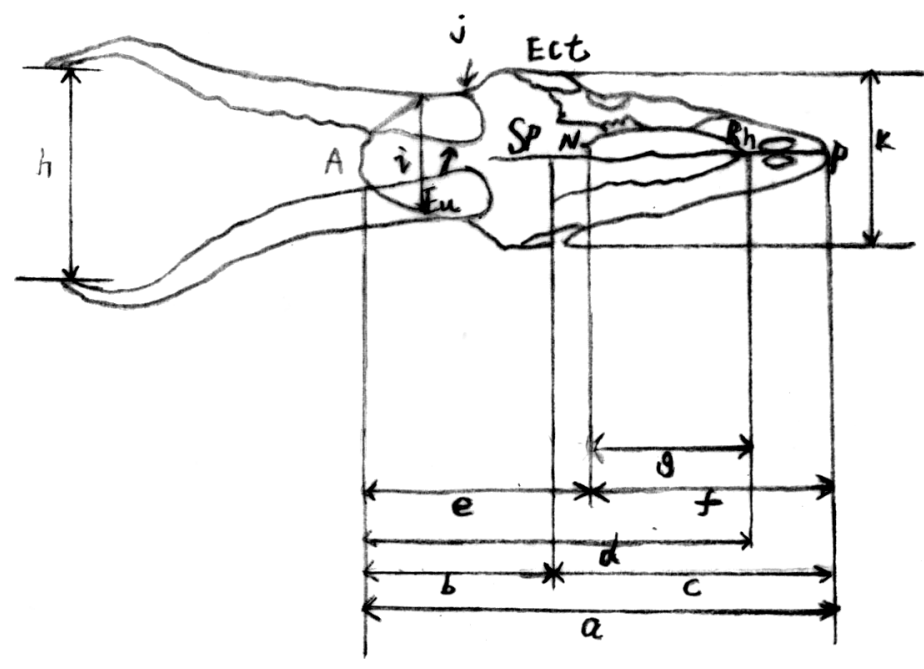

Fig. 1. Measurement of the skull of the Tibetan gazelle (dorsal view): Akrokranion (A), Ectorbitale (Ect), Euryon (Eu), Nasion (N), P (prosthion), Rhinion (Rh), Supraorbitale (Sp); Skull length (a), Upper neurocranium length (b), Facial length (c), Short upper cranium length (d), Cranial length (e), Viscerocranium length (f ), Nasal suture length (g), Least distance between the horn core tips (h), Maximum width of the neurocranium (i), Least diameter of the horn core base (j), Maximum zygomatic width (k).

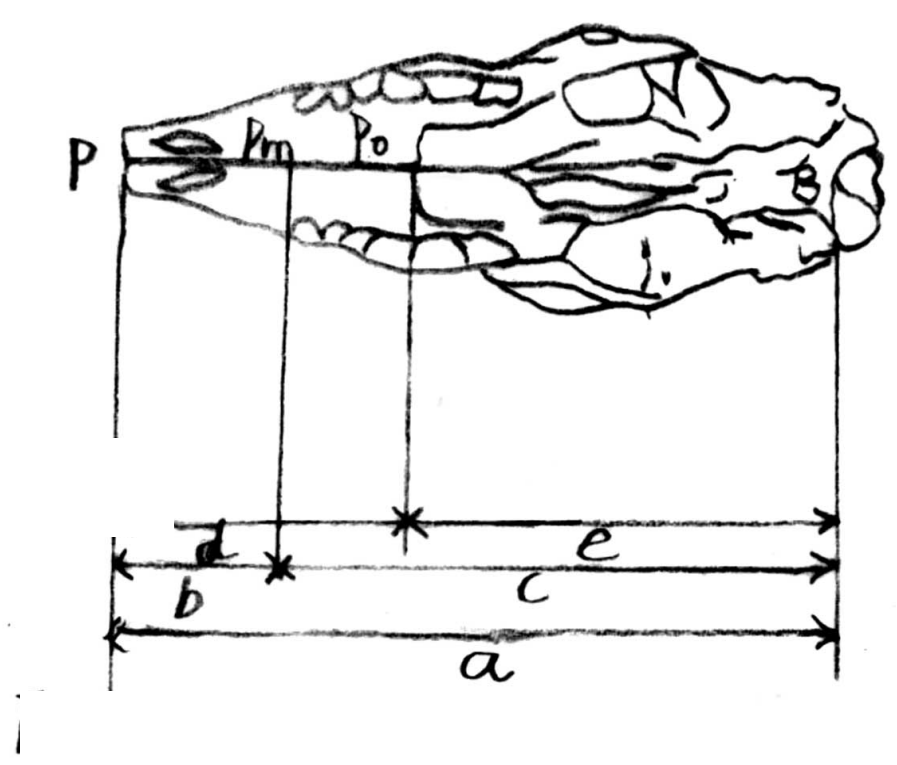

Fig. 2. Measurement of the skull of the Tibetan gazelle (ventral view): Basion (B), Pm (Premolare), Po (Palatinoorale), P (prosthion); Basal length (a), Premolare-prosthion (b), Short skull length (c), Oral palatal length (d), Basion- Palatinoorale (e).

length (Palatinoorale-prosthion), Basion- Palatinoorale, lateral length of the premaxilla (Nasointermaxillare-prosthion), lateral facial length (ectorbitale-prosthion), Short lateral facial length (entorbitale-prosthion), Length of the braincase (ectorbitaleopisthion). Greatest inner length of the orbit, Greatest inner height of the orbit.

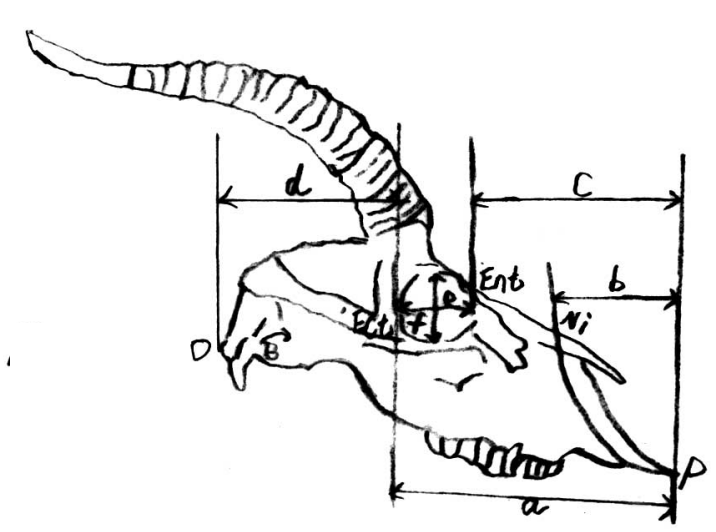

Fig. 3. Measurement of the skull of the Tibetan gazelle (lateral view): Basion(B), Ectorbitale(Ect), Entorbitale (Ent), Nasointermaxillare (Ni), Opisthion (O), P (prosthion); Lateral facial length (a), Lateral length of the premaxilla (b), Short lateral facial length (c), Length of the braincase (d), Greatest inner length of the orbit (e), Greatest inner height of the orbit (f).

Skull index (maximum zygomatic width $\mathrm{x}$ 100/skull length), cranial index (maximum width of neurocranium x 100/cranial length), facial index (maximum zygomatic width x100/viscerocranial length)

\section{RESULT AND DISCUSSION}

It was observed that the Tibetan gazelle had a small head, with S-shaped horns. A skull length of 19.60 $\pm 0.23 \mathrm{~cm}$ and a maximum zygomatic width of $8.47 \pm$ $0.12 \mathrm{~cm}$ were obtained. Procapra includes three extant species: P. gutturosa, P. picticaudata, and P. przewalskii. The skulls of Tibetan gazelle were smaller than those of the other two members of the genus (Groves). Vladimir \& Anna (1997) argued that the horns of male Tibetan gazelle is longer than $250 \mathrm{~mm}$ and procapra przewalskii is shorter than $250 \mathrm{~mm}$, but the measurement we got from the specimen is $24.60 \pm 0.14 \mathrm{~cm}$. So the $250 \mathrm{~mm}$ may not be the discrimination of them.

Craniometric measurements of the skulls were evaluated. The investigated features are presented as the mean \pm SD in Table I. The indices and ratios of the adult Procapra gutturosa were calculated by using the investigated features. A skull index of $43.22 \pm 0.44$, a cranial index of $58.37 \pm 0.80$ and a facial index of $116.37 \pm 1.24$ were obtained. According to Onar, the values were very close to index data of the dolichocephalic breeds. 
Table I. The mean value of skull measurements of the Tibetan gazelle $(\mathrm{cm})$.

\begin{tabular}{lcc}
\hline & Mean & SD \\
\hline Maximum zygomatic width & 8.47 & 0.12 \\
Skull length & 19.60 & 0.23 \\
Short upper cranium length & 16.34 & 0.21 \\
Cranial length & 12.30 & 0.13 \\
Viscerocranium length & 8.14 & 0.07 \\
Nasal suture length & 7.28 & 0.13 \\
Facial length & 11.12 & 0.08 \\
Upper neurocranium length & 9.01 & 0.12 \\
Maximum width of the neurocranium & 7.18 & 0.10 \\
Least distance between the horn core tips & 17.83 & 0.23 \\
Least diameter of the horn core base & 0.43 & 0.04 \\
Basal length & 16.04 & 0.07 \\
Premolare-prosthion & 5.24 & 0.11 \\
Short skull length & 10.18 & 0.09 \\
Oral palatal length & 7.31 & 0.15 \\
Basion-palatinoorale & 8.76 & 0.14 \\
lateral length of the premaxilla & 4.15 & 0.05 \\
Lateral facial length & 10.56 & 0.10 \\
Short lateral facial length & 8.35 & 0.07 \\
Length of the braincase & 5.24 & 0.17 \\
Greatest inner length of the orbit & 3.87 & 0.06 \\
Greatest inner height of the orbit & 3.34 & 0.08 \\
\hline
\end{tabular}

The vertical distances from the facial tuberosity to the infraorbital canal and from the infraorbital canal to the root of the alveolar tooth were $3.21 \pm 0.12 \mathrm{~cm}$ and $2.45 \pm 0.09 \mathrm{~cm}$ respectively. The data obtained in this study are of great significance in the clinical treatments of diseases and make clear the classification of procapra (Olopade \& Onwuka, 2005).

ACKNOWLEDGEMENT. The study received financial support from Scientific Research Foundation of Qujing Normal University (2009ZD005).

ZHU, L. Estudios craneométricos en el cráneo de la Gacela del Tibet (Procapra Picticaudata). Int. J. Morphol., 30(1):196-198, 2012.

RESUMEN: Un total de 10 cráneos de gacela tibetana se utilizaron en este estudio. Mediciones craniométricos para 22 diferentes partes de los cráneos fueron realizadas. Los índices craneales y sus razones fueron calculadas. Un índice de cráneo de 43,22 \pm 0,44 , un índice craneal de 58,37 $\pm 0,80$ y un índice facial de 116,37 $\pm 1,24$ se obtuvieron.

PALABRAS CLAVE: Craneometría; Cráneo; Procapra Picticaudata.

\section{REFERENCES}

Brehm, H. K.; Loeffler, H. \& Komeyli, H. Skull shape in the dog. Anat. Histol. Embryol., 14:324-31, 1985.

Groves, C. P. On the gazelles of the genus Procapra Hodgson, 1846. Z. Saugetierkd., 32:144-9, 1967.

Leslie, Jr. D. M. Procapra picticaudata (Artiodactyla: Bovidae). Mamm. Species: 42:138-48, 2010.

Olopade, J. O. \& Onwuka, S. K. Some aspects of the clinical anatomy of the mandibular and maxillofacial regions of the west African dwarf goat in Nigeria. Int. J. Morphol., 23:33-6, 2005.

Onar, V. A morphometric study on the skull of the German shepherd dog (Alsatian). Anat. Histol. Embryol., 28:2536, 1999.

Onar, V.; Ozcan, S. \& Pazvant, G. Skull typology of adult male Kangal dogs. Anat. Histol. Embryol., 30:41-8, 2001.

Özcan, S.; Aksoy, G.; Kürtül, I’ .; Aslan, K. \& Özüdog`ru, Z. A comparative Morphometric Study on the Skull of the Tuj and Morkaraman Sheep. Kafkas Univ. Vet. Fak. Derg., 16:111-4, 2010.

Sarma, K. Morphological and craniometrical studies on the skull of Kagani Goat (Capra hircus) of Jammu Region. Int. J. Morphol., 24:449-55, 2006.

Simoens, P.; Poels, P. \& Lauwers, H. Morphometric analysis of the foramen magnum in Pekingese dogs. Am. J. Vet. Res., 55:34-9, 1994.

Vladimir, E. S. \& Anna A. L., Procapra gutturosa. Mamm. Species, 571:1-5, 1997.

Correspondence to:

Lei Zhu

San Jiang road, QiLin District

Yunnan-Guizhou Plateau Institute of Biodiversity

QuJing Normal University

QuJing, Yunnan, 655011, P. R.

CHINA

Email: Zhulei82@gmail.com

Received: 31-07-2011

Accepted: 21-11-2011 